\title{
Bioinformatics Evaluation of SPATA19 Gene Expression in Different Parts of Brain
}

\author{
Mahsa Zargar' ${ }^{1}$ (D) Sina Majidian² (D) Mohammad Hossein Modarressi ${ }^{*}$ (iD, Sasan Shabani ${ }^{1}$ (D) \\ 1. Department of Medical Genetics, School of Medicine, Tehran University of Medical Sciences, Tehran, Iran. \\ 2. Department of Electrical Engineering, School of Electrical Engineering, Iran University of Science \& Technology, Tehran, Iran.
}

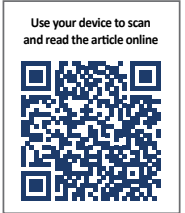

Citation Zargar M, Majidian S, Modarressi MH, Shabani S. Bioinformatics Evaluation of SPATA19 Gene Expression in Different Parts of Brain. Research in Molecular Medicine. 2021; 9(2):139-144. https://doi.org/10.32598/rmm.9.2.2

doi https://doi.org/10.32598/rmm.9.2.2

\section{(i) $(5)$}

Article Type:

Short Communication

Article info:

Received: 1 Feb 2021

Revised: 6 March 2021

Accepted: 28 Mar 2021

Keywords:

Bioinformatics, Brain,

Testis, SPATA19, Gene

Expression Omnibus (GEO)

\begin{abstract}
A B S T RA C T
Background: Determining the expression pattern of testis genes in the brain is essential for understanding tissue functions and correlation or inter-correlation between testis and the brain. In this study, we examined spermatogenesis-associated 19 (SPATA19 gene) expression in 10 parts of the brain with bioinformatics analysis.

Materials and Methods: The public dataset GSE46706, including 1231 samples originated from 134 Caucasian individuals, was downloaded from NCBI Gene Expression Omnibus (GEO). SPATA19 gene expression in the cerebellar cortex, frontal cortex, hippocampus, medulla, occipital cortex, putamen, substantia nigra, temporal cortex, thalamus, and white matter was examined against each other using R software and the t-test.

Results: Out of 10 brain parts examined, the cerebellar cortex and white matter showed the highest expression, and the temporal cortex showed the lowest expression of the gene. So the cerebellar cortex had a $5.6 \%$ and $6.2 \%$ increase in gene expression relative to the putamen and temporal cortex with $\mathrm{P}$ values of $6.04 \mathrm{e}-13$ and $2.15 \mathrm{e}-17$, respectively. Also, the white matter had a $4 \%$ increase in gene expression over the temporal cortex with a P value of $1.89 \mathrm{e}-13$.
\end{abstract}

Conclusion: SPATA19 had more expression in the cerebellar cortex and white matter than other brain parts. These two parts make up the cerebellum.

\section{Introduction}

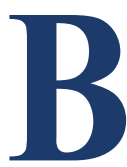

rain and testis are similar in many features, such as blood barriers and expression patterns [1]. This similarity has been repeatedly confirmed by many studies [2-5]. The relationship between some parameters of semen quality and intelligence as well as testis and brain dysfunction has already been identified. By comparing these two tissues, we can understand their common molecular properties. Despite a lot of studies done on this topic, many issues are still unclear. Therefore, much research is still needed in this field to take steps towards understanding the functions of the brain and testis and improving treatment strategies [6]. Similar expression patterns of testis genes in the brain can

\section{"Corresponding Author:}

Mohammad Hossein Modarressi, PhD.

Address: Department of Medical Genetics, School of Medicine, Tehran University of Medical Sciences, Tehran, Iran.

Phone: +98 (218) 8953005

E-mail: modaresi@tums.ac.ir 
provide a basis for understanding tissue functions and correlation or inter-correlation between testis and brain [1]. Spermatogenesis-associated 19 (SPATA19) is a testisspecific gene mainly expressed in testis and located on chromosome 11q25 [7, 8]. Two coding experimental and two non-coding predicted transcripts were registered in the RefSeq database of NCBI $[9,10]$. This gene is also expressed in the brain, and its amount in the cerebellum is more than the whole brain [11]. However, this gene expression has been reported negative in some studies and positive in some others. Interestingly, the studies had not mentioned the sample location of the brain $[12,13]$. This missing information suggests that the expression of this gene may vary in different parts of the brain, which has not been studied in previous studies.

In this study, we evaluated SPATA19 gene expression in the cerebellar cortex, frontal cortex, hippocampus, medulla, occipital cortex, putamen, substantia nigra, temporal cortex, thalamus, and white matter with bioinformatics analysis of UK Brain Expression Consortium data.

\section{Materials and Methods}

\section{Data collection}

The public GEO dataset GSE46706 was downloaded from NCBI Gene Expression Omnibus (GEO). In this study, 1231 samples were taken from 134 brains of postmortem humans. So, expression profiling of 10 parts of the brain was examined by array, and its data were published in the GEO database [14].

\section{Statistical analysis}

In all assays, statistical analysis was performed using $\mathrm{R}$ software. The percentage change of expression was examined using the t-test. $P$ values less than 0.05 were considered significant.

\section{Results}

Expression Analysis of SPATA19 in Different Parts of the Brain

SPATA19 gene expression in 10 parts of the brain was evaluated by the bioinformatics method so that the expression of this gene increases in the temporal cortex, putamen, hippocampus, medulla, thalamus, substantia nigra, frontal cortex, occipital cortex, white matter, and cerebellar cortex. Based on the results, the cerebellar cortex and white matter showed the highest expression, and the temporal cortex showed the lowest expression.
Cerebellar cortex had a 5.6\% and $6.2 \%$ increase relative to putamen and temporal cortex with $\mathrm{P}$ values of $6.04 \mathrm{e}-$ 13 and $2.15 \mathrm{e}-17$, respectively. Also, the white matter had a $4 \%$ increase over the temporal cortex with a $P$ value of $1.89 \mathrm{e}-13$ (Figure 1).

\section{Discussion}

The human brain and testis had a similar gene expression pattern [1]. Examining this expression pattern can provide a basis for understanding tissue functions and correlation or inter-correlation between testis and brain [1]. Although several studies have been conducted in this field, some aspects of this issue are still unclear. Therefore, it is necessary to do more research in this field to provide a basis for understanding the brain's functions and testes and improving treatment strategies [6]. In this study, the expression data of 1231 samples from 134 post-mortem human brains presented in the public GEO dataset GSE46706 were analyzed [14]. Our results showed that SPATA19 testis-specific is expressed in the brain in addition to the testis. However, the expression pattern was different in distinct parts of the brain; for example, its expression was lowest in the temporal cortex and highest in the cerebellar cortex and white matter.

In 2015, Duff $M$ et al. performed RNA-Seq of total RNA for 20 human tissues. In this study, SPATA19 gene expression in fetal brain, cerebellum, and whole-brain was found $0.014,0.023$, and 0.001 RPKM, respectively [11]. Human Protein Atlas database (https://www. proteinatlas.org/ENSG00000166118-SPATA19/brain) showed that human expression of this gene was present in the cerebral cortex based on Consensus Human Genome Dataset, in the cerebral cortex, basal ganglia and cerebellum based on GTEX Human RNA-Seq dataset, and in cerebral cortex based on FANTOM5 Human Brain CAGE dataset. Mouse expression of this gene was found in the cerebral cortex, olfactory region, hippocampal formation, amygdala, basal ganglia, thalamus, hypothalamus, midbrain, corpus callosum, pons, and medulla based on the HPA Mouse Brain RNA-Seq dataset and in the cerebral cortex, olfactory region, hippocampal formation, amygdala, basal ganglia, thalamus, hypothalamus, midbrain, cerebellum, pons, and medulla based on Allen Mouse Brain ISH dataset. These data are compatible with our findings.

On the other hand, some studies showed contradictory results. In 2003, Miyamoto et al. examined the expression of this gene with nested RT-PCR method in various organs of humans, mice, and rats, including brain and testis. The result showed expression was only in testis 


\begin{tabular}{|c|c|c|c|c|c|c|c|c|c|c|}
\hline \multicolumn{11}{|c|}{ Change in Spata19 expression (\%) } \\
\hline & $\begin{array}{c}\text { cerebellar } \\
\text { cortex }\end{array}$ & $\begin{array}{l}\text { frontal } \\
\text { cortex }\end{array}$ & \begin{tabular}{|c|} 
hippocam \\
pus
\end{tabular} & medulla & $\begin{array}{c}\text { occipital } \\
\text { cortex }\end{array}$ & putamen & $\begin{array}{c}\text { substantia } \\
\text { nigra }\end{array}$ & $\begin{array}{c}\text { temporal } \\
\text { cortex }\end{array}$ & thalamus & $\begin{array}{l}\text { white } \\
\text { matter }\end{array}$ \\
\hline \begin{tabular}{|c} 
cerebellar \\
cortex
\end{tabular} & 0 & 3.1 & 4 & 3.8 & 2 & 5.6 & 3.3 & 6.2 & 3.7 & 0.7 \\
\hline \begin{tabular}{|l|} 
frontal \\
cortex
\end{tabular} & -3.1 & 0 & 0.9 & 0.7 & -1 & 2.5 & 0.2 & 3 & 0.6 & -2.3 \\
\hline \begin{tabular}{|c|} 
hippocam \\
pus
\end{tabular} & -4 & -0.9 & 0 & -0.1 & -1.9 & 1.6 & -0.6 & 2.1 & -0.2 & -3.2 \\
\hline medulla & -3.8 & -0.7 & 0.1 & 0 & -1.8 & 1.7 & -0.5 & 2.3 & -0.1 & -3.1 \\
\hline $\begin{array}{c}\text { occipital } \\
\text { cortex }\end{array}$ & -2 & 1 & 1.9 & 1.8 & 0 & 3.6 & 1.3 & 4.1 & 1.7 & -1.3 \\
\hline putamen & -5.6 & -2.5 & -1.6 & -1.7 & -3.6 & 0 & -2.2 & 0.5 & -1.8 & -4.7 \\
\hline $\begin{array}{c}\text { substantia } \\
\text { nigra }\end{array}$ & -3.3 & -0.2 & 0.6 & 0.5 & -1.3 & 2.2 & 0 & 2.8 & 0.4 & -2.6 \\
\hline $\begin{array}{c}\text { temporal } \\
\text { cortex }\end{array}$ & -6.2 & -3 & -2.1 & -2.3 & -4.1 & -0.5 & -2.8 & 0 & -2.3 & -5.2 \\
\hline thalamus & -3.7 & -0.6 & 0.2 & 0.1 & -1.7 & 1.8 & -0.4 & 2.3 & 0 & -3 \\
\hline $\begin{array}{c}\text { white } \\
\text { matter }\end{array}$ & -0.7 & 2.3 & 3.2 & 3.1 & 1.3 & 4.7 & 2.6 & 5.2 & 3 & 0 \\
\hline
\end{tabular}

\begin{tabular}{|c|c|c|c|c|c|c|c|c|c|c|}
\hline \multicolumn{11}{|c|}{ P-value in SPATA19 expression } \\
\hline & $\begin{array}{c}\text { cerebellar } \\
\text { cortex }\end{array}$ & $\begin{array}{l}\text { frontal } \\
\text { cortex }\end{array}$ & \begin{tabular}{|c|} 
hippocam \\
pus
\end{tabular} & medulla & $\begin{array}{c}\text { occipital } \\
\text { cortex }\end{array}$ & putamen & $\begin{array}{c}\text { substantia } \\
\text { nigra }\end{array}$ & \begin{tabular}{|c|} 
temporal \\
cortex
\end{tabular} & thalamus & $\begin{array}{l}\text { white } \\
\text { matter }\end{array}$ \\
\hline $\begin{array}{c}\text { cerebellar } \\
\text { cortex }\end{array}$ & 1 & $7.09 \mathrm{E}-06$ & $1.86 \mathrm{E}-08$ & $1.40 \mathrm{E}-07$ & 0.00379889 & $6.04 \mathrm{E}-13$ & $3.87 \mathrm{E}-05$ & $2.15 \mathrm{E}-17$ & $2.67 \mathrm{E}-07$ & 0.31995192 \\
\hline $\begin{array}{l}\text { frontal } \\
\text { cortex }\end{array}$ & $7.09 \mathrm{E}-06$ & 1 & 0.21349471 & 0.30731716 & 0.14070665 & 0.00119408 & 0.78151846 & $2.10 \mathrm{E}-05$ & 0.3808235 & 0.00069456 \\
\hline \begin{tabular}{|c|} 
hippocam \\
pus
\end{tabular} & $1.86 \mathrm{E}-08$ & 0.21349471 & 1 & 0.85608842 & 0.0080244 & 0.03790562 & 0.42252603 & 0.00282689 & 0.74259779 & $5.90 \mathrm{E}-06$ \\
\hline medulla & $1.40 \mathrm{E}-07$ & 0.30731716 & 0.85608842 & 1 & 0.01660744 & 0.02882127 & 0.53344957 & 0.00216444 & 0.88700097 & $2.47 \mathrm{E}-05$ \\
\hline $\begin{array}{c}\text { occipital } \\
\text { cortex }\end{array}$ & 0.00379889 & 0.14070665 & 0.0080244 & 0.01660744 & 1 & $7.64 \mathrm{E}-06$ & 0.12110981 & 3.30E-08 & 0.02376576 & 0.06247315 \\
\hline putamen & $6.04 \mathrm{E}-13$ & 0.00119408 & 0.03790562 & 0.02882127 & 7.64E-06 & 1 & 0.00951288 & 0.49641055 & 0.01991111 & $6.03 \mathrm{E}-10$ \\
\hline $\begin{array}{c}\text { substantia } \\
\text { nigra }\end{array}$ & 3.87E-05 & 0.78151846 & 0.42252603 & 0.53344957 & 0.12110981 & 0.00951288 & 1 & 0.00071121 & 0.62036881 & 0.00135942 \\
\hline $\begin{array}{c}\text { temporal } \\
\text { cortex } \\
\end{array}$ & $2.15 \mathrm{E}-17$ & $2.10 \mathrm{E}-05$ & 0.00282689 & 0.00216444 & $3.30 \mathrm{E}-08$ & 0.49641055 & 0.00071121 & 1 & 0.00126729 & $1.89 \mathrm{E}-13$ \\
\hline thalamus & 2.67E-07 & 0.3808235 & 0.74259779 & 0.88700097 & 0.02376576 & 0.01991111 & 0.62036881 & 0.00126729 & 1 & 4.26E-05 \\
\hline $\begin{array}{l}\text { white } \\
\text { matter }\end{array}$ & 0.31995192 & 0.00069456 & $5.90 \mathrm{E}-06$ & $2.47 \mathrm{E}-05$ & 0.06247315 & $6.03 \mathrm{E}-10$ & 0.00135942 & $1.89 \mathrm{E}-13$ & $4.26 \mathrm{E}-05$ & 1 \\
\hline
\end{tabular}

Figure 1. The percentage change and P-value of SPATA19 gene expression in different parts of human brain

The percentage indicated in each cell indicates an increased percentage of expression in a row relative to the Table's column. For example, SPATA19 gene expression in the cerebellar cortex is $6.2 \%$ higher than temporal cortex with a P value of 2.15e-17. In this study, $P$-values less than 0.05 are considered significant.

[12]. In 2017, a study by Iris E Jansen et al. suggested that SPATA19 was one of the rare variants involved in Parkinson disease [15]. This expression or non-expression observed in the normal brain of different reports may be due to several reasons, including differences in the sensitivity of methods used, age of samples, brain sampling locations, personalized expression of samples, etc. This gene may be involved in the pathogenesis of Parkinson disease by changing the expression dose or transcript type of gene. Because some studies did not in- 
dicate the location and time of brain development, the expression of this gene may occur at a specific time and place of brain development. Therefore, it is necessary to perform more accurate experimental analyzes.

\section{Conclusion}

In brief, the current study demonstrated SPATA19 gene expression in different parts of the brain. This gene had more expression in the cerebellar cortex and white matter than other parts. These two parts make up the cerebellum which is an important center for coordination and learning of necessary movements to regulate body posture and balance. Therefore, it is suggested that future studies investigate the role of SPATA19 in normal cerebellar function.

\section{Availability of data and materials}

The public dataset GSE46706 was downloaded from the NCBI Gene Expression Omnibus (GEO). The data used to support the finding of this study are available from the corresponding author upon request.

\section{Ethical Considerations}

\section{Compliance with ethical guidelines}

All analyses were consistent with guidelines published by Tehran University of Medical Science.

\section{Funding}

This study was funded by Tehran University of Medical Sciences (Grant No.: 96-04-30-36990).

\section{Authors' contribution's}

Conceptualization and supervision: Mohammad Hossein Modarressi; Methodology: Mahsa Zargar and Sina Majidian; Investigation, writing - original draft, and writing - review \& editing: Mahsa Zargar and Sasan Shabani; Data collection, data analysis: Mahsa Zargar and Sina Majidian.

\section{Conflict of interest}

The authors declared no competing interests.

\section{Acknowledgements}

We would like to thank Ryten $\mathrm{M}$ et al., who released and shared their datasets on the GEO database.

\section{References}

[1] Guo J, Zhu P, Wu C, Yu L, Zhao S, Gu X. In silico analysis indicates a similar gene expression pattern between human brain and testis. Cytogenet Genome Res. 2003; 103(1-2):58-62. [DOI:10.1159/000076290] [PMID]

[2] Muslimov IA, Lin Y, Heller M, Brosius J, Zakeri Z, Tiedge H. A small RNA in testis and brain: Implications for male germ cell development. J Cell Sci. 2002; 115(Pt 6):1243-50. [DOI:10.1242/jcs.115.6.1243] [PMID]

[3] Ibberson M, Riederer BM, Uldry M, Guhl B, Roth J, Thorens B. Immunolocalization of GLUTX1 in the testis and to specific brain areas and vasopressin-containing neurons. Endocrinology. 2002; 143(1):276-84. [DOI:10.1210/endo.143.1.8587] [PMID]

[4] Ghabriel MN, Lu JJ, Hermanis G, Zhu C, Setchell BP. Expression of a blood-brain barrier-specific antigen in the reproductive tract of the male rat. Reproduction. 2002; 123(3):389-97. [DOI:10.1530/rep.0.1230389] [PMID]

[5] Pascal JM, Chennathukuzhi VM, Hecht NB, Robertus JD. Mouse testis-brain RNA-binding protein (TB-RBP): Expression, purification and crystal X-ray diffraction. Acta Crystallogr D Biol Crystallogr. 2001; 57(Pt 11):1692-4. [DOI:10.1107/ S0907444901014548] [PMID]

[6] Matos B, Publicover SJ, Castro LFC, Esteves PJ, Fardilha M. Brain and testis: More alike than previously thought? Open Biol. 2021; 11(6):200322. [DOI:10.1098/rsob.200322] [PMID] [PMCID]

[7] Miryounesi M, Nayernia K, Mobasheri MB, Dianatpour M, Oko R, Savad S, et al. Evaluation of in vitro spermatogenesis system effectiveness to study genes behavior: Monitoring the expression of the testis specific 10 (Tsga10) gene as a model. Arch Iran Med. 2014; 17(10):692-7. [PMID]

[8] Strupp M, Maul S, Konte B, Hartmann AM, Giegling I, Wollenteit $\mathrm{S}$, et al. A variation in FGF14 is sssociated with downbeat Nystagmus in a genome-wide association study. Cerebellum. 2020; 19(3):348-57. [DOI:10.1007/s12311-02001113-x] [PMID] [PMCID]

[9] Brown GR, Hem V, Katz KS, Ovetsky M, Wallin C, Ermolaeva $\mathrm{O}$, et al. Gene: A gene-centered information resource at NCBI. Nucleic Acids Res. 2015; 43(Database issue):D36-42. [DOI:10.1093/nar/gku1055] [PMID] [PMCID]

[10] Pruitt KD, Brown GR, Hiatt SM, Thibaud-Nissen F, Astashyn A, Ermolaeva O, et al. RefSeq: An update on mammalian reference sequences. Nucleic Acids Res. 2014; 42(Database issue):D756-63. [DOI:10.1093/nar/gkt1114] [PMID] [PMCID]

[11] Duff MO, Olson S, Wei X, Garrett SC, Osman A, Bolisetty $\mathrm{M}$, et al. Genome-wide identification of zero nucleotide recursive splicing in Drosophila. Nature. 2015; 521(7552):3769. [DOI:10.1038/nature14475] [PMID] [PMCID]

[12] Miyamoto T, Sengoku K, Hasuike S, Takuma N, Hayashi H, Yamashita T, et al. Isolation and expression analysis of the human testis-specific gene, SPERGEN-1, a spermatogenic cell-specific gene-1. J Assist Reprod Genet. 2003; 20(2):101-4. [PMID]

[13] Zargar M, Jamshidizad A, Rahim-Tayefeh A, Hashemi E, Shabani S, Shamsara M, et al. Spata19 inactivation is a cause of oligospermia. Res Mol Med. 2021; 9(1):29-38. [DOI:10.32598/rmm.9.1.4] 
[14] Trabzuni D; United Kingdom Brain Expression Consortium (UKBEC), Thomson PC. Analysis of gene expression data using a linear mixed model/finite mixture model approach: Application to regional differences in the human brain. Bioinformatics. 2014; 30(11):1555-61. [DOI:10.1093/ bioinformatics/btu088] [PMID]

[15] Jansen IE, Gibbs JR, Nalls MA, Price TR, Lubbe S, van Rooij J, et al. Establishing the role of rare coding variants in known Parkinson's disease risk loci. Neurobiol Aging. 2017; 59:220.e11220.e18. [DOI:10.1016/j.neurobiolaging.2017.07.009] [PMID] 
This Page Intentionally Left Blank 